\title{
Sustainable Conversion of Agriculture and Food Waste into Activated Carbons Devoted to Fluoride Removal from Drinking Water in Senegal
}

\author{
Mohamad M. Diémé ${ }^{1}$, Maxime Hervy², Saïdou N. Diop ${ }^{1}$, Claire Gérente ${ }^{2}$, Audrey Villot ${ }^{2}$, Yves Andres² \& Courfia K. \\ Diawara $^{1}$ \\ ${ }^{1}$ Laboratoire de Chimie et Physique des Matériaux, Université Assane Seck, BP 523, Ziguinchor, Sénégal \\ ${ }^{2}$ Ecole des Mines de Nantes, laboratoire GEPEA, UMR CNRS 6144, 4 rue Alfred Kastler, BP 20722, 44307 Nantes \\ cedex 3, France \\ Correspondence: Saïdou N. Diop, Laboratoire de Chimie et Physique des Matériaux, Université Assane Seck, BP 523, \\ Ziguinchor, Sénégal. E-mail: sndiop@univ-zig.sn
}

Received: October 8, 2015 Accepted: November 6, 2015 Online Published: November 25, 2015

doi:10.5539/ijc.v8n1p8 URL: http://dx.doi.org/10.5539/ijc.v8n1p8

\begin{abstract}
The objective of this study was to investigate the production of activated carbons (AC) from cashew shells, and millet stalks and their efficiency in fluoride retention. These agricultural residues are collected from Senegal. It is known that some regions of Sénégal, commonly called the groundnut basin, are affected by a public health problem caused by an excess of fluoride in drinking water used by these populations. The activated carbons were produced by a combined pyrolysis and activation with water steam; no other chemical compounds were added. Then, activated carbonaceous materials obtained from cashew shells and millet stalks were called CS- $\mathrm{H}_{2} \mathrm{O}$ and $\mathrm{MS}-\mathrm{H}_{2} \mathrm{O}$ respectively. $\mathrm{CS}-\mathrm{H}_{2} \mathrm{O}$ and MS- $\mathrm{H}_{2} \mathrm{O}$ show very good adsorbent features, and present carbon content ranges between $71 \%$ and $86 \%$. The BET surface areas are $942 \mathrm{~m}^{2} \mathrm{~g}^{-1}$ and $1234 \mathrm{~m}^{2} \cdot \mathrm{g}^{-1}$ for CS- $\mathrm{H}_{2} \mathrm{O}$ and $\mathrm{MS}-\mathrm{H}_{2} \mathrm{O}$ respectively. A third activated carbon produced from food wastes and coagulation-flocculation sludge $\left(\mathrm{FW} / \mathrm{CFS}-\mathrm{H}_{2} \mathrm{O}\right)$ was produced in the same conditions. Carbon and calcium content of FW/CFS- $\mathrm{H}_{2} \mathrm{O}$ are 32.6 and $39.3 \%$ respectively. The kinetics sorption were performed with all these activated carbons, then the pseudo-first equation was used to describe the kinetics sorption. Fluoride adsorption isotherms were performed with synthetic and natural water with the best activated carbon from kinetics sorption, Langmuir and Freundlich models were used to describe the experimental data. The results showed that carbonaceous materials obtained from $\mathrm{CS}-\mathrm{H}_{2} \mathrm{O}$ and $\mathrm{MS}-\mathrm{H}_{2} \mathrm{O}$ were weakly efficient for fluoride removal. With $\mathrm{FW} / \mathrm{CFS}-\mathrm{H}_{2} \mathrm{O}$, the adsorption capacity is $28.48 \mathrm{mg} \cdot \mathrm{g}^{-1}$ with $\mathrm{r}^{2}=0.99$ with synthetic water.
\end{abstract}

Keywords: activated carbon, adsorption, calcium, fluoride, cashew shell, millet stalk, food waste

\section{Introduction}

In recent years, many studies have been done in order to remove the high concentration of many contaminants from drinking water such as fluoride, lead, arsenic, copper and nitrate (Sud, Mahajan, \& Kaur, 2008). It is known that fluoride is an essential element in drinking water. This trace element is actively involved in the health of teeth, especially in the prevention of dental cavities and plays an important role in bone strength. However, when the fluoride concentration in drinking water is higher than $1.5 \mathrm{mg} . \mathrm{L}^{-1}$, it may cause harmful effects on human health namely dental fluorosis and skeletal fluorosis at concentrations above $4 \mathrm{mg} . \mathrm{L}^{-1}$ (Srivastav, Singh, Srivastava, \& Sharma, 2013; Diallo, Diop, Diémé, \& Diawara, 2015). In the world, it is estimated that more than 200 million people are exposed to drinking water with a fluoride concentration that exceeds the WHO guideline $\left(1.5 \mathrm{mg} \cdot \mathrm{L}^{-1}\right)$ (Bhatnagar, Kumar, \& Sillanpää, 2011). Many countries around the world such as India, Bangladesh, Nepal, Sénégal, USA, and Mexico are concerned by fluoride exposure because of the high numbers of their populations that present the effects caused by the high concentration of fluoride in their drinking water (Fawell et al., 2006; Bibi, Farooqi, Hussain, \& Haider, 2015).

Thus, several processes for fluoride removal have been developed. Some are based on membrane technologies such as nanofiltration and reverse osmosis ( Diop, Diémé, \& Diawara, 2015), while others use adsorption technologies such as adsorption into clay or activated carbon (Yadav, Abbassi, Gupta, \& Dadashzadeh, 2013). Membrane technology is well known for its effectiveness in fluoride removal, but its high operating cost may remain a problem for developing countries. Many papers also report the use of the adsorption process to remove fluoride in drinking water. Activated carbons are widely used as adsorbents for pollutant removal due to their interesting physical and chemical properties. Moreover, activated carbons could be low-cost materials if produced from agricultural waste collected freely in the 
fields. Previous papers studied the efficiency of activated carbon in fluoride uptake. Consequently, for enhancing the uptake of fluoride by activated carbon these authors have modified the adsorbent by impregnating it with the calcium solution (Hernández-Montoya, Ramírez-Montoya, Bonilla-Petriciolet, \& Montes-Morán, 2012).

The purpose of this study is to produce and characterize low-cost activated carbon and to study their efficiency in fluoride sorption. The activated carbons were produced from millet stalk, cashew shell and a mixture of food waste and coagulation-flocculation sludge (FW/CFS). Then these three carbonaceous materials were used to study fluoride adsorption efficiency. The Langmuir and Freundlich models were used to describe the isotherms experimental data and the pseudo first order equation was also used to describe the kinetic data.

\section{Materials and Methods}

\subsection{Production of Carbonaceous Materials}

Millet stalks and cashew shells named respectively MS and CS, were used as precursors. Millet stalks were cut into small pieces to facilitate their introduction to the reactor, while cashew shells were left in their original state. The carbonization (or pyrolysis) was conducted under an inert atmosphere $\left(0.5 \mathrm{~L} / \mathrm{min}\right.$ of $\left.\mathrm{N}_{2}\right)$ up to $850{ }^{\circ} \mathrm{C}$ with a temperature ramp of $10{ }^{\circ} \mathrm{C} / \mathrm{min}$ in a batch quartz rotary furnace (HTR $11 / 150$, Carbolite). At $850{ }^{\circ} \mathrm{C}$, the step of activation was started with an injection of steam $\left(0.7 \mathrm{~mL}\right.$ of water. $\left.\mathrm{min}^{-1}\right)$ as activating gas for 80 minutes. The cooling of the furnace was still realized under inert atmosphere. For the FW/CFS, first, pyrolysis char from $50 \mathrm{wt} \% \mathrm{FW}$ and 50 $\mathrm{wt} \% \mathrm{CFS}$ was produced in semi-continuous screw reactor by slow pyrolysis (heating rate of $22{ }^{\circ} \mathrm{C} \cdot \mathrm{min}^{-1}$ ) at $700{ }^{\circ} \mathrm{C}$ during $30 \mathrm{~min}$. The details of the experimental procedure were described in a previous paper (Mura, Debono, Villot, \& Paviet, 2013). The char was then activated with steam to produce $\mathrm{FW} / \mathrm{CFS}-\mathrm{H}_{2} \mathrm{O}$. The same experimental procedure as that described above was used for the activation process. AC were washed with deionized water, and dried at $105^{\circ} \mathrm{C}$ before being characterized. This method was adapted from the previous work realized by the research team (Torres-Perez, Gerente, \& Andres, 2012).

\subsection{Characterization of Activated Carbon}

Elemental analysis of CHNSO was performed using the apparatus Flash EA 1112, Thermofinnigan. The total ash content and $\mathrm{pH}_{\mathrm{PZC}}$ (point of zero charge) determination of each activated carbon were carried out following a methodology previously described (Torres-Perez, Gerente, \& Andres, 2012). For the $\mathrm{pH}_{\mathrm{PZC}}, 100 \mathrm{~mL}$ of $0.01 \mathrm{~mol} . \mathrm{L}^{-1}$ $\mathrm{NaCl}$ solution was placed in a closed polyethylene bottle. The $\mathrm{pH}$ was adjusted between 2 and 12 by adding $\mathrm{HCl}$ or $\mathrm{NaOH} 0.1 \mathrm{~mol} . \mathrm{L}^{-1}$ solution. Then, $0.05 \mathrm{~g}$ of each sample was added in the closed polyethylene bottle that was set stirring for 5 days at the room temperature before measuring the final $\mathrm{pH}$. Then the final $\mathrm{pH}$ was plotted against the initial $\mathrm{pH}$, and the point where this curve crosses the line $\mathrm{pH}_{\text {final }}=\mathrm{pH}_{\text {initial }}$ represents the $\mathrm{pH}_{\mathrm{PZC}}$.

The porous properties of activated carbon were deduced from nitrogen adsorption isotherms at $77 \mathrm{~K}$ (ASAP 2020 Micromeritics). The scanning electron microscopy (SEM) was carried out using the apparatus JOEL JSM 5800LV, allowing the observation of the porous structure of carbonaceous materials. To determine the presence of the other elements such as iron and calcium quantitative analysis was performed by using EDX-800HS apparatus.

\subsection{Fluoride Adsorption}

All the measurements of fluoride concentration were performed by using a UV-1800 spectrophotometer. Firstly, the suitable wavelength for these measurements was determined. Thus, a solution of $2 \mathrm{mg} . \mathrm{L}^{-1}$ was prepared from an initial fluoride solution of 0.2 g.L. $\mathrm{L}^{-1}$ prepared by dissolution of $\mathrm{NaF}$ in deionized water (Milli-Q Millipore $18.0 \mathrm{M} \Omega \mathrm{cm}^{-1}$, resistivity). Then a square cell sample was filled with $2 \mathrm{mg} . \mathrm{L}^{-1}$ of fluoride solution up to the mark before it was placed in the sample holder. From there, the peak wavelength was determined from the spectrum curve. Thus the maximum wavelength used in this study was $618.3 \mathrm{~nm}$. Analytical measurements were obtained with a quantification limit of 0.25 $\mathrm{mg} \mathrm{L}^{-1}$ and a detection limit of $0.12 \mathrm{mg} \mathrm{L}^{-1}$. The quantification limit is the lowest level that can be reliably measured.

All three activated carbons were used in the fluoride adsorption in deionized water, before the better of these adsorbents were used for the isotherm adsorption both in deionized and natural water.

For the sorption kinetic experiments, batch contact time experiments were conducted at $21^{\circ} \mathrm{C}$ by stirring $0.8 \mathrm{~g}$ of sorbent with $1000 \mathrm{~mL}$ of fluoride solution $\left(5 \mathrm{mg} \mathrm{L}^{-1}\right)$ at $250 \mathrm{rpm}$. The $\mathrm{pH}$ was measured before adding the sorbent in the polyethylene reactor and measured at the end of kinetic. Then the equilibrium time between the solid and the solution was determined by plotting the fluoride concentration versus time. The pseudo first order sorption model proposed by (Ho \& Mckay, 1998) was used to describe the kinetic curves as indicate by the following equation:

$$
\frac{d q_{t}}{d t}=k_{1}\left(q_{e}-q_{t}\right)
$$


Where $q_{e}$ and $q_{t}$ are the sorption capacities at equilibrium and at time $\mathrm{t}$ respectively $\left(\mathrm{mg} \cdot \mathrm{g}^{-1}\right)$ and $k_{1}$ is the rate constant of pseudo first order sorption $\left(\mathrm{min}^{-1}\right)$. Then the integration with the conditions follow, $t=0$ to $t=t$ and $q_{t}=0$ to $q_{t}=q_{t}$, the linear form obtained is expressed as follow:

$$
\log \left(q_{e}-q_{t}\right)=\log q_{e}-\frac{k_{1}}{2.303} t
$$

The parameters $q_{e}$ and $k_{1}$ were calculated by plotting $\log \left(q_{e}-q_{t}\right)$ versus $t$.

Bath adsorption isotherms were conducted at $21{ }^{\circ} \mathrm{C}$ with $250 \mathrm{~mL}$ of synthetic solution from 3 to $25 \mathrm{mg}$. $\mathrm{L}^{-1}$ of fluoride and $0.175 \mathrm{~g}$ of adsorbent. Then the reactors have been stirred for $120 \mathrm{~min}$ at $250 \mathrm{rpm}$. The $\mathrm{pH}$ was measured before adding the sorbent and at the end of the experiment, the values ranged between 5 and 9. Langmuir and Freundlich models were used to describe the experimental data of the isotherms (Freundlich, H.M., 1906); (Langmuir, I., 1918). The Langmuir equation is describes below:

$$
q_{e}=\frac{q_{m} b C_{e}}{1+b C_{e}}
$$

Where $b$ is the equilibrium constant of the reaction $\left(\mathrm{L}_{\mathrm{mg}} \mathrm{mg}^{-1}\right), q_{m}$ and $C_{e}$ are the maximum adsorption capacity $\left(\mathrm{mg} . \mathrm{g}^{-1}\right)$ and the amount of fluoride at equilibrium $\left(\mathrm{mg} . \mathrm{L}^{-1}\right)$, respectively.

The Freundlich equation is given below:

$$
q_{e}=K_{f} C_{e}^{n}
$$

Where $K_{f} \quad\left(\mathrm{mg} \cdot \mathrm{g}^{-1}\right) /\left(\mathrm{mg} \cdot \mathrm{L}^{-1}\right)^{1 / \mathrm{n}}$ and $n$ the Freundlich isotherm constant related to the adsorption capacity.

In sorption processes, it is know that the presence of other ions can contribute to a competitive effect between the ions, leading to a modification of the adsorption capacities. Thus the isotherm adsorption was performed with natural water, the composition of which is given in Table 1.

Table 1. Mineral content of natural water

\begin{tabular}{lcccccccc}
\hline Elements & $\mathrm{Ca}^{2+}$ & $\mathrm{Mg}^{2+}$ & $\mathrm{Na}^{+}$ & $\mathrm{K}^{+}$ & $\mathrm{HCO}_{3}{ }^{-}$ & $\mathrm{Cl}^{-}$ & $\mathrm{SO}_{4}{ }^{2-}$ & $\mathrm{NO}_{3}{ }^{-}$ \\
\hline $\mathrm{C}\left(\mathrm{mg} . \mathrm{L}^{-1}\right)$ & 4.7 & 1.8 & 5.9 & 2.8 & 40.3 & 1.2 & 0.2 & 0.5 \\
\hline
\end{tabular}

The potential effect of these ions into the adsorption capacity will be discussed below.

\section{Results and Discussions}

\subsection{Characterization of Activated Carbon}

The chemical characterization (elemental analysis and $\mathrm{pH}_{\mathrm{PZC}}$ ) and the physical characterization (BET surface area

\begin{tabular}{|c|c|c|c|c|c|c|c|c|c|}
\hline \multirow{2}{*}{ Material } & \multicolumn{4}{|c|}{ Mass fraction $/ \%$} & \multirow{2}{*}{$\mathrm{pH}_{\mathrm{PZC}}$} & \multirow{2}{*}{$\begin{array}{c}\mathrm{S}_{\mathrm{BET}} \\
/ \mathrm{m}^{2} \cdot \mathrm{g}^{-1}\end{array}$} & \multirow{2}{*}{$\begin{array}{c}\mathrm{V}_{\text {micro }} \\
/ \mathrm{cm}^{3} \cdot \mathrm{g}^{-1}\end{array}$} & \multirow{2}{*}{$\begin{array}{c}\mathrm{V}_{\text {meso }} \\
/ \mathrm{cm}^{3} \cdot \mathrm{g}^{-1}\end{array}$} & \multirow{2}{*}{$\begin{array}{c}\text { Total porous } \\
\text { volume } / \mathrm{cm}^{3} . \mathrm{g}^{-}\end{array}$} \\
\hline & $\mathrm{C}$ & $\mathrm{H}$ & $\mathrm{O}$ & Ash & & & & & \\
\hline $\mathrm{MS}-\mathrm{H}_{2} \mathrm{O}$ & 86.0 & 0.8 & 12.2 & 0.1 & 8.0 & 1324 & 0.588 & 0.033 & 0.665 \\
\hline $\mathrm{CS}-\mathrm{H}_{2} \mathrm{O}$ & 71.0 & 0.8 & 21.0 & 6.5 & 10.6 & 942 & 0.415 & 0.045 & 0.504 \\
\hline $\mathrm{FW} / \mathrm{CFS}-\mathrm{H}_{2}$ & 32.6 & 0.9 & 6.6 & 62.2 & 9.8 & 225 & 0.098 & 0.036 & 0.164 \\
\hline
\end{tabular}
analysis) are given in the Table 2.

Table 2. Properties of activated carbons

As several activated carbons produced at laboratory scale, the major element contents of them are $\mathrm{C}, \mathrm{O}$ and $\mathrm{H}$. The carbon percentage showed in Table 1 is $86.0 \%, 71.0 \%$ and $32.6 \%$ for the MS- $\mathrm{H}_{2} \mathrm{O}, \mathrm{CS}-\mathrm{H}_{2} \mathrm{O}$ and FW/CFS- $\mathrm{H}_{2} \mathrm{O}$ respectively. The values of carbon content of $\mathrm{MS}-\mathrm{H}_{2} \mathrm{O}$ and $\mathrm{CS}-\mathrm{H}_{2} \mathrm{O}$ lead to real carbonaceous materials. In the literature, similar values were obtained during research activities for the activated carbons production from agricultural wastes (Rashidi, Yusup, Ahmad, Mohamed, \& Hameed, 2012; Torres-Perez, Gerente, \& Andres, 2012; Sekirifa, Hadj-Mahammed, Pallier, Baameur, Richard, \& Al-Dujaili, 2013). In contrast, the carbon content of activated carbon from the mixture of food waste and coagulation-flocculation sludge $\left(\mathrm{FW} / \mathrm{CFS}-\mathrm{H}_{2} \mathrm{O}\right)$ is low $(32.6 \%)$. This carbon content may negatively impact on the BET surface area. As an identical production method was used, the differences in the properties of the activated carbons are only assigned to the precursor nature. The second major element of the activated carbon is oxygen. Its content is $12.2 \%, 21.0 \%$ and $6.6 \%$ for the MS- $\mathrm{H}_{2} \mathrm{O}, \mathrm{CS}-\mathrm{H}_{2} \mathrm{O}$ and $\mathrm{FW} / \mathrm{CFS}-\mathrm{H}_{2} \mathrm{O}$ respectively. These values of oxygen content are close to those obtained by Torres-Perez, Gerente, \& Andres, (2012) that have characterized two commercial granular activated carbons. 
The ash content is $0.1 \%$ and $6.5 \%$ for $\mathrm{MS}-\mathrm{H}_{2} \mathrm{O}$ and CS- $\mathrm{H}_{2} \mathrm{O}$ respectively and these values are close to those obtained in the literature ( Torres-Perez, Gerente, \& Andres, 2012). However, the ash content in FW/CFS- $\mathrm{H}_{2} \mathrm{O}$ is significantly higher: $62.2 \%$, this value is so high that it can explain the low carbon content of this material. Generally when an activated carbon presents a low carbon content and a high ash content, its BET surface area is low. Finally all these carbonaceous materials reveal a basic $\mathrm{pH}_{\mathrm{PZC}}$, ranging from 8.0 to 10.6. Thus the surface charge of carbonaceous materials is negative.

As described above, the BET surface area is performed with ASAP 2020 Micromeritics by nitrogen adsorption at $77 \mathrm{~K}$. The results are presented in the Table 2. Thus the BET surface area of the MS- $\mathrm{H}_{2} \mathrm{O}, \mathrm{CS}-\mathrm{H}_{2} \mathrm{O}$ and FW/CFS- $\mathrm{H}_{2} \mathrm{O}$ is 1324 $\mathrm{m}^{2} \cdot \mathrm{g}^{-1}, 942 \mathrm{~m}^{2} \mathrm{~g}^{-1}$ and $225 \mathrm{~m}^{2} \cdot \mathrm{g}^{-1}$ respectively. For the MS- $\mathrm{H}_{2} \mathrm{O}$ and $\mathrm{CS}-\mathrm{H}_{2} \mathrm{O}$, their high content of carbon and a low ash content probably allow these carbonaceous materials to develop the BET surface area above $800 \mathrm{~m}^{2} \cdot \mathrm{g}^{-1}$. During their work in 2012, Torres-Pérez et al, produced two activated carbons from agricultural wastes, and their BET surface areas ranged between 821 and $829 \mathrm{~m}^{2} \mathrm{~g}^{-1}$. Beside the high BET surface area developed by $\mathrm{MS}-\mathrm{H}_{2} \mathrm{O}$ and $\mathrm{CS}-\mathrm{H}_{2} \mathrm{O}$, as expected, the $\mathrm{FW} / \mathrm{CFS}-\mathrm{H}_{2} \mathrm{O}$ has the lowest value $\left(218 \mathrm{~cm}^{2} \mathrm{~g}^{-1}\right)$.

With SEM micrograph and EDX spectra of these activated carbons (data not shown) it was possible to appreciate the difference between the macropores upon the surface of each sample. Then with the EDX spectra, the high presence of calcium was found in the $\mathrm{FW} / \mathrm{CFS}-\mathrm{H}_{2} \mathrm{O}$ with a percentage of $39.3 \%$.

Concerning the total porous volumes, the values obtained with the $\mathrm{MS}-\mathrm{H}_{2} \mathrm{O}, \mathrm{CS}-\mathrm{H}_{2} \mathrm{O}$ and $\mathrm{FW} / \mathrm{CFS}-\mathrm{H}_{2} \mathrm{O}$ are 0.665 $\mathrm{cm}^{3} \cdot \mathrm{g}^{-1}, 0.504 \mathrm{~cm}^{3} \cdot \mathrm{g}^{-1}$ and $0.164 \mathrm{~cm}^{3} \mathrm{~g}^{-1}$ (Table 2). As for the BET surface areas, the activated carbons from millet stalks and cashew shells present the highest total porous volumes. However, all these activated carbons have a developed microporous nature. The nitrogen adsorption isotherms obtained confirm the microporous nature of these activated carbons. MS- $\mathrm{H}_{2} \mathrm{O}$ and $\mathrm{CS}-\mathrm{H}_{2} \mathrm{O}$ develop a microporous volume ranging between 0.588 and $0.415 \mathrm{~cm}^{3} \cdot \mathrm{g}^{-1}$; for the $\mathrm{FW} / \mathrm{CFS}-\mathrm{H}_{2} \mathrm{O}$, the microporous volume is $0.098 \mathrm{~cm}^{3} \mathrm{~g}^{-1}$. These values of microporous volume obtained in this study can be compared to data found by Bandosz \& Ania, (2006). The mesoporous volumes are $0.033,0.045$ and $0.036 \mathrm{~cm}^{3} \mathrm{~g}^{-1}$ for MS- $\mathrm{H}_{2} \mathrm{O}, \mathrm{CS}-\mathrm{H}_{2} \mathrm{O}$ and FW/CFS- $\mathrm{H}_{2} \mathrm{O}$ respectively.

\subsection{Fluoride Removal with Carbonaceous Materials}

\subsubsection{Sorption Kinetics}

With MS- $\mathrm{H}_{2} \mathrm{O}, \mathrm{CS}-\mathrm{H}_{2} \mathrm{O}$ and FW/CFS- $\mathrm{H}_{2} \mathrm{O}$, batch contact experiments were performed. The kinetics curves of CS- $\mathrm{H}_{2} \mathrm{O}$ and $\mathrm{FW} / \mathrm{CFS}-\mathrm{H}_{2} \mathrm{O}$ are depicted in Figure 1. MS- $\mathrm{H}_{2} \mathrm{O}$ displayed a fluoride uptake almost null, thus the kinetic curve of this material is not plotted here.

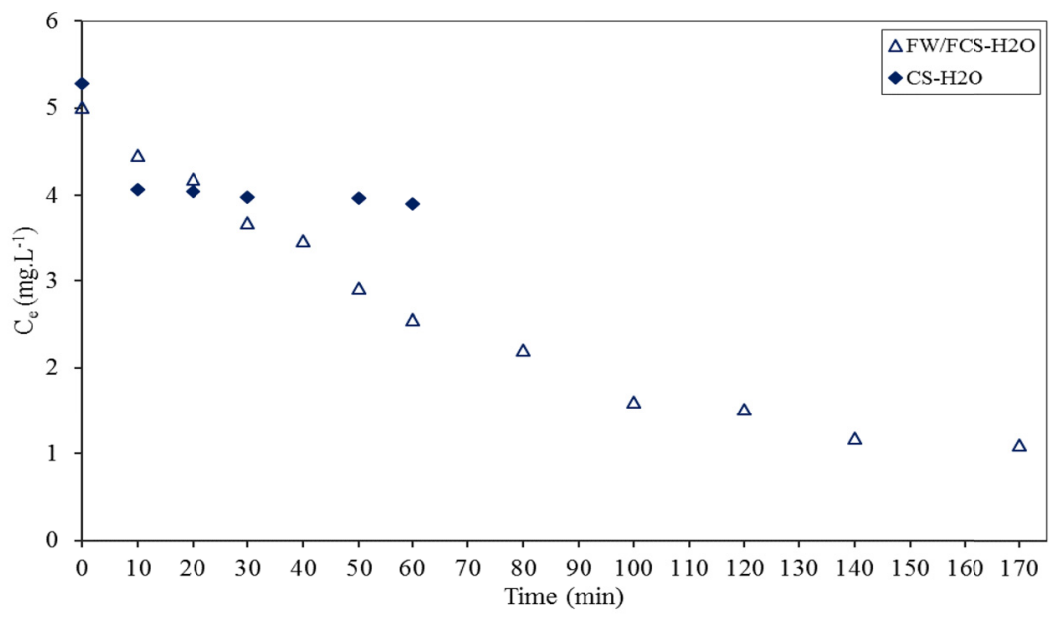

Figure 1. Kinetic decay curves for fluoride uptake on CS- $\mathrm{H}_{2} \mathrm{O}$ and FW/CFS- $\mathrm{H}_{2} \mathrm{O}$

From these kinetic decay curves for removal of fluoride on these activated carbons, the optimal contact time is determined as $20 \mathrm{~min}$ and $2 \mathrm{~h}$ for $\mathrm{CS}-\mathrm{H}_{2} \mathrm{O}$ and FW/CFS- $\mathrm{H}_{2} \mathrm{O}$ respectively. Thus, experimental adsorption capacity for CS- $\mathrm{H}_{2} \mathrm{O}$ is $1.61 \mathrm{mg} \cdot \mathrm{g}^{-1}$, while for $\mathrm{FW} / \mathrm{CFS}-\mathrm{H}_{2} \mathrm{O}$, the experimental adsorption capacity reach $5.29 \mathrm{mgg}^{-1}$ at the equilibrium time. Table 3 presents the parameters $q_{e}$ and $k_{1}$ calculated from linear form of pseudo first order equation by plotting $\log \left(q_{e}-q_{t}\right)$ versus $t$.

Table 3. Parameters of pseudo first order kinetic model

\begin{tabular}{ccccc}
\hline Material & $q_{0} \exp \left(\mathrm{mg} \cdot \mathrm{g}^{-1}\right)$ & $q_{0, \mathrm{cal}}\left(\mathrm{mg} \cdot \mathrm{g}^{-1}\right)$ & $k_{1}\left(\mathrm{~min}^{-1}\right)$ & $\mathrm{r}^{2}$ \\
\hline $\mathrm{CS}-\mathrm{H}_{2} \mathrm{O}$ & 1.61 & 0.43 & 0.1 & 0.82 \\
FW/CFS- $\mathrm{H}_{2} \mathrm{O}$ & 5.29 & 8.59 & 0.063 & 0.91 \\
\hline
\end{tabular}


The pseudo first order model tested in this study does not describe very well the experimental data especially for the experimental data obtained with $\mathrm{CS}-\mathrm{H}_{2} \mathrm{O}$ that $\mathrm{r}^{2}=0.82$. With its low adsorption capacity of fluoride this material will not be used for the equilibrium adsorption isotherms. It appears here that the BET surface area and the carbon content are not decisive factors for the fluoride adsorption because $\mathrm{CS}-\mathrm{H}_{2} \mathrm{O}$ has the higher BET surface area and carbon content than FW/CFS- $\mathrm{H}_{2} \mathrm{O}$. Furthermore, the experimental fluoride adsorption capacity of $5.29 \mathrm{mg} \cdot \mathrm{g}^{-1}$ is reached and the pseudo first order describe better the experimental data with $\mathrm{r}^{2}=0.91$ even if the fluoride adsorption capacity calculated is overestimate $\left(8.59 \mathrm{mg} \cdot \mathrm{g}^{-1}\right)$. The pseudo first order equation does not fit well the experimental data of kinetic sorption. Generally, this model is applicable over the initial 20 to $30 \mathrm{~min}$ of the kinetic sorption (Ho \& McKay, 1998; Gerente, V.K.C. Lee, Le Cloirec, \& McKay, 2007; Islam \& Patel, 2011).

\subsubsection{Adsorption Isotherms}

Adsorption isotherms were carried out during $2 \mathrm{~h}$ of contact time between the fluoride solution with initial concentrations ranging between 3 to $25 \mathrm{mg} . \mathrm{L}^{-1}$, and $\mathrm{pH}$ ranging from 5 to 9 . The experimental data are plotted while the Langmuir and Freundlich equations are used to model the experimental curve of the fluoride uptake (Figure 2). The Langmuir isotherm reflects the monolayer adsorption while the Freundlich isotherm shows the multilayer adsorption.

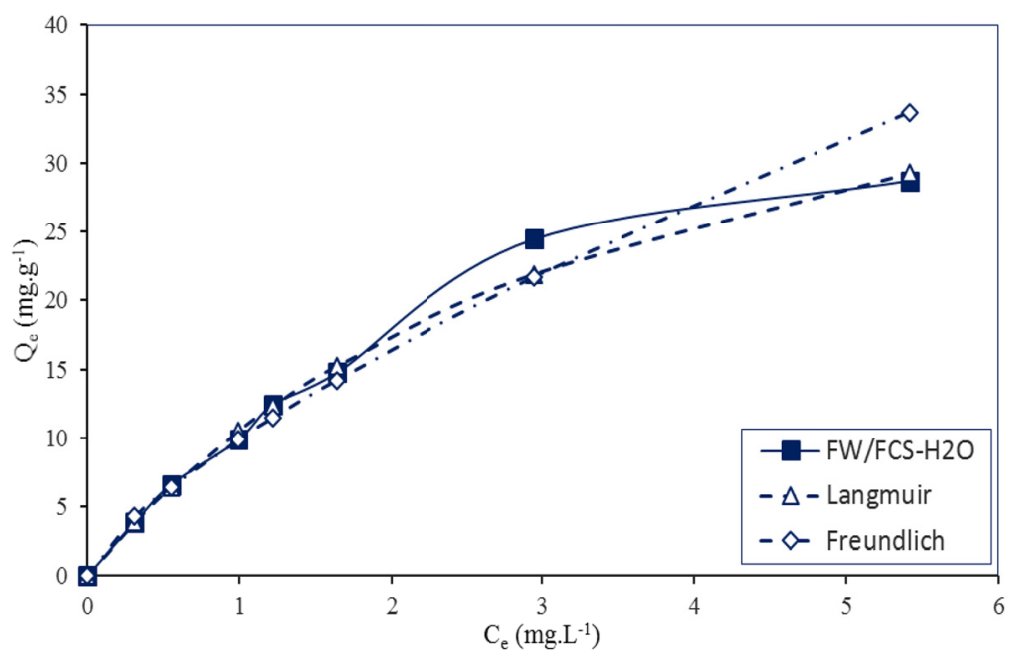

Figure 2. Experimental adsorption isotherm of fluoride using the Langmuir and Freundlich models

From these curves, the Langmuir model fits the experimental data very well with $\mathrm{r}^{2}=0.99$ as well as the Freundlich model $\left(r^{2}=0.98\right)$. In the Table 4, the modelling parameters of Langmuir and Freundlich are listed.

Table 4. Isotherm parameters of fluoride adsorption on FW/CFS- $\mathrm{H}_{2} \mathrm{O}$

\begin{tabular}{|c|c|c|c|c|c|c|}
\hline \multirow{2}{*}{ Material } & \multicolumn{3}{|c|}{ Langmuir } & \multicolumn{3}{|c|}{ Freundlich } \\
\hline & $q_{m}\left(\mathrm{mg} \cdot \mathrm{g}^{-1}\right)$ & $b\left(\mathrm{~L}^{\mathrm{m} \mathrm{mg}^{-1}}\right)$ & $\mathrm{r}^{2}$ & $K_{f}\left(\left(\mathrm{mg} \cdot \mathrm{g}^{-1}\right) /\left(\left(\mathrm{mg} \cdot \mathrm{L}^{-1}\right)^{1 / \mathrm{n}}\right)\right.$ & $n$ & $\mathrm{r}^{2}$ \\
\hline $\mathrm{FW} / \mathrm{FCS}-\mathrm{H}_{2} \mathrm{O}$ & 28.48 & 0.28 & 0.99 & 9.95 & 0.72 & 0.98 \\
\hline
\end{tabular}

Concerning the Freundlich model, $K_{f}$ is found to $9.95\left(\mathrm{mg} \cdot \mathrm{g}^{-1}\right) /\left(\mathrm{mg} \cdot \mathrm{L}^{-1}\right)^{1 / \mathrm{n}}$ with $\mathrm{r}^{2}=0.98$ and $\mathrm{n}=0.72$. Regarding the Langmuir model, the adsorption capacity $q_{m}$ is $28.48 \mathrm{mg} \cdot \mathrm{g}^{-1}$ and equilibrium constant of the reaction $b=0.28$ L.mg ${ }^{-1}$. The value of $q_{m}$ calculated from the Langmuir model is similar to the experimental data which is $28.73 \mathrm{mg} . \mathrm{g}^{-1}$. This match indicates that a monolayer adsorption is involved in fluoride sorption and only the interactions between the fluoride species and the adsorbent surface occur. Despite its low BET surface area and the low carbon content than CS- $\mathrm{H}_{2} \mathrm{O}$, the FW/FCS- $\mathrm{H}_{2} \mathrm{O}$ can be an alternative and efficient sorbent for fluoride removal from drinking water. This high adsorption capacity suggests that the high presence of calcium upon the adsorbent plays a very important role in the uptake of fluoride. These three activated carbons were produced by adapting the same method and none have been modified. Indeed during their activity research, Hernández-Montoya et al., (2012) used pecan nut shells as precursor for the production of activated carbon. The activated carbons were then impregnated with a calcium solution extracted from egg shells. The calcium content in their activated carbon are ranged between 1.6 and $4.48 \%$. Using the Langmuir model, the activated carbon with the highest calcium content reached the better adsorption capacity with the value of 2.51 $\mathrm{mgg}^{-1}$. The BET surface area of this modified activated carbon is $17 \mathrm{~m}^{2} \mathrm{~g}^{-1}$. This adsorption capacity remains significantly lower than that obtained in our study with the non-modified FW/FCS- $\mathrm{H}_{2} \mathrm{O}\left(28.48 \mathrm{mg} . \mathrm{g}^{-1}\right)$ which naturally contains calcium species. Sivasankar, Rajkumar, Murugesh, \& Darchen, (2012) obtained an adsorption capacity of $22.33 \mathrm{mg} . \mathrm{g}^{-1}$ using the Langmuir model with carbonaceous material from tamarind fruit shell impregnated in ammonium carbonate solution. The calcium content and BET surface area of this modified carbonaceous material were $7.2 \%$ and $473 \mathrm{~m}^{2} \cdot \mathrm{g}^{-1}$, respectively. At the present time, many research activities are being done to remove excess 
fluoride from drinking water on the adsorbents and a high adsorption capacity are reached (Srivastav, Singh, Srivastava, \& Sharma, 2013; Zhang, Lu, Lin, Su, \& Zhang, 2014; Bibi, Farooqi, Hussain, \& Haider, 2015).

Figure 3, depicts the initial concentration of fluoride against the percentage of removal fluoride obtained with deionized water and natural water.

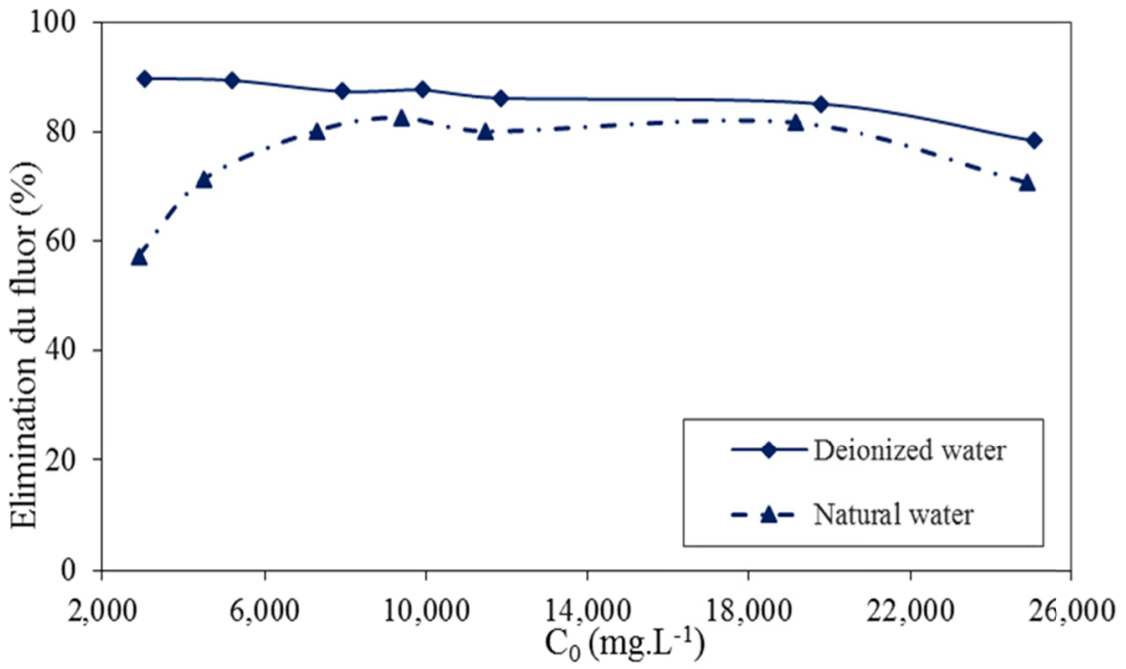

Figure 3. Percentage of removal fluoride in synthetic and natural water

Indeed the hypothesis stated above is verified according to the shape of the curves obtained with natural water and deionized water (synthetic water in the figure). The presence of other ions promoted a competitive effect between the fluoride ion $\left(\mathrm{F}^{-}\right)$and those of natural water (Table 1). It is probably the anions present in natural water which are responsible for the effect of competition with the fluoride anion. The potential anions in natural water which can be competitor anion are $\mathrm{HCO}_{3}{ }^{-}, \mathrm{Cl}^{-}, \mathrm{SO}_{4}{ }^{2-}$ and $\mathrm{NO}_{3}{ }^{-}$. Moreover, a possible attraction could take place between the fluoride anion in solution and calcium cations in $\mathrm{FW} / \mathrm{FCS}-\mathrm{H}_{2} \mathrm{O}$.

Finally, the results obtained in this study and those reported in the literature have shown the issue of fluoride worldwide can be solved by using activated carbons produced from various agricultural residues or waste as adsorbents.

\section{Conclusion}

In the present study, three activated carbons were prepared from millet stalks $\left(\mathrm{MS}-\mathrm{H}_{2} \mathrm{O}\right)$, cashew shells $\left(\mathrm{CS}-\mathrm{H}_{2} \mathrm{O}\right)$, food wastes and coagulation-flocculation sludge $\left(\mathrm{FW} / \mathrm{CFS}-\mathrm{H}_{2} \mathrm{O}\right)$. The $\mathrm{MS}-\mathrm{H}_{2} \mathrm{O}$ and $\mathrm{CS}-\mathrm{H}_{2} \mathrm{O}$ have developed a great chemical and physical characteristic properties. Then they were studied as sorbents for fluoride removal from drinking water. Only FW/CFS- $\mathrm{H}_{2} \mathrm{O}$ had shown a great potential for fluoride removal with percentages above 70 and $80 \%$ with natural and synthetic water respectively. From kinetic sorption, the equilibrium time is $2 \mathrm{~h}$ and the pseudo first order does not fit the experimental data very well. Regarding equilibrium data, the experimental data are better described by Langmuir model than by the Freundlich model. A high adsorption capacity is provided by Langmuir in deionized water $\left(28.48 \mathrm{mgg}^{-1}\right)$. With an initial fluoride concentration of $7 \mathrm{mgL}^{-1}$, the remaining fluoride concentration measured after $2 \mathrm{~h}$ equilibrium time with $\mathrm{FW} / \mathrm{CFS}-\mathrm{H}_{2} \mathrm{O}$ is $1.4 \mathrm{mg} . \mathrm{L}^{-1}$. The limit established by the WHO is $1.5 \mathrm{mgL}^{-1}$ for drinking water. Generally, the drinking water which presents excess fluoride concentration ranges between 3 and 8 mg. $\mathrm{L}^{-1}$. That means $\mathrm{FW} / \mathrm{CFS}-\mathrm{H}_{2} \mathrm{O}$ can be used in water treatment especially for fluoride removal.

\section{Acknowledgments}

This research was supported by the French Embassy in Senegal via its Cultural and Cooperation Department which allows Senegal PhD students to realize scientific stays in French laboratory. All the experiments of this study were carried out in the Energy and Environmental Engineering Department (DSEE) of Ecole des Mines de Nantes-France. And M. Hervy wishes to thank "Institut Carnot M.I.N.E.S" for its financial support.

\section{References}

Bandosz, T. J., \& Ania, C. O. (2006). Chapter 4 Surface chemistry of activated carbons and its characterization. In Teresa J. Bandosz (éd.). Interface Science and Technology, 7159-7229. http://dx.doi.org/10.1016/S1573-4285(06)80013-X.

Bhatnagar, A., Kumar, E., \& Sillanpää, M. (2011). Fluoride removal from water by adsorption-A review. Chemical Engineering Journal, 171(3), 811-840. http://dx.doi.org/10.1016/j.cej.2011.05.028. 
Bibi, S., Farooqi, A., Hussain, K., \& Haider, N. (2015). Evaluation of industrial based adsorbents for simultaneous removal of arsenic and fluoride from drinking water. Journal of Cleaner Production, 87, 882-896. http://dx.doi.org/10.1016/j.jclepro.2014.09.030.

Diallo, M. A., Diop, S. N., Diémé, M. M., \& Diawara, C. K. (2015). Efficiency of nanofiltration membrane TFC-SR3 and SelRo MPF-34 for partial elimination of fluoride and salinity from drinking water. Journal of Water Resource and Protection, 7, 457-462. http://dx.doi.org/10.4236/jwarp.2015.77043.

Fawell, J., Bailey, K., Chilton, J., Dahi, E., Fewtrell, L., \& Magara, Y. (2006). Fluoride in drinking water, WHO-IWA (p. 1-144). WHO.

Freundlich, H. M. (1906). Over the adsorption in solution. J. Phys. Chem., 57, 385-470.

Gerente, C., V. K. C., Lee, L., Cloirec, P., \& McKay, G. (2007). Application of Chitosan for the Removal of Metals From Wastewaters by Adsorption-Mechanisms and Models Review. Critical Reviews in Environmental Science and Technology - CRIT REV ENVIRON SCI TECHNOL, 37(1), 41-127. http://dx.doi.org/10.1080/10643380600729089

Hernández-Montoya, V., Ramírez-Montoya, L. A., Bonilla-Petriciolet, A., \& Montes-Morán, M. A. (2012). Optimizing the removal of fluoride from water using new carbons obtained by modification of nut shell with a calcium solution from egg shell. Biochemical Engineering Journal, 62, 1-7. http://dx.doi.org/10.1016/j.bej.2011.12.011

Ho, Y. S., \& McKay, G. (1998). A Comparison of Chemisorption Kinetic Models Applied to Pollutant Removal on Various Sorbents. Process Safety and Environmental Protection, 76(4), 332-340.

Ho, Y. S., \& Mckay, G. (1998). Kinetic Models for the Sorption of Dye from Aqueous Solution by Wood. Process Safety and Environmental Protection, 76(2), 183-191. http://dx.doi.org/10.1205/095758298529326.

Islam, M., \& Patel, R. (2011). Thermal activation of basic oxygen furnace slag and evaluation of its fluoride removal efficiency. Chemical Engineering Journal, 169(1-3), 68-77. http://dx.doi.org/10.1016/j.cej.2011.02.054.

Langmuir, I. (1918). The adsorption of gases on plane surface of glass, mica and platinum. J. Am. Chem. Soc., 40, 1331-1403.

Muro, E., Debono, O., Villot, A., Paviet, F., (2013) Pyrolysis of biomass in semi-industrial scale reactor: Study of the fuel-nitrogen oxidation during combustion of volatiles. Biomass Bioenergy 59, 187-194. http://dx.doi.org/10.1016/j.biombioe.2013.09.001.

Rashidi, N. A., Yusup, S., Ahmad, M. M., Mohamed, N. M., \& Hameed, B. H. (2012). Activated Carbon from the Renewable Agricultural Residues Using Single Step Physical Activation: A Preliminary Analysis. APCBEE Procedia, 3, 84-92. http://dx.doi.org/10.1016/j.apcbee.2012.06.051.

Sekirifa, M. L., Hadj-Mahammed, M., Pallier, S., Baameur, L., Richard, D., \& Al-Dujaili, A. H. (2013). Preparation and characterization of an activated carbon from a date stones variety by physical activation with carbon dioxide. Journal of Analytical and Applied Pyrolysis, 99, 155-160. http://dx.doi.org/10.1016/j.jaap.2012.10.007.

Sivasankar, V., Rajkumar, S., Murugesh, S., \& Darchen, A. (2012). Tamarind (Tamarindus indica) fruit shell carbon: A calcium-rich promising adsorbent for fluoride removal from groundwater. Journal of Hazardous Materials, 225-226, 164-172. http://dx.doi.org/10.1016/j.jhazmat.2012.050.015.

Srivastav, A. L., Singh, P. K., Srivastava, V., \& Sharma, Y. C. (2013). Application of a new adsorbent for fluoride removal from aqueous solutions. Journal of Hazardous Materials, 263, Part 2, 342-352. http://dx.doi.org/10.1016/j.jhazmat.2013.04.017.

Sud, D., Mahajan, G., \& Kaur, M. P. (2008). Agricultural waste material as potential adsorbent for sequestering heavy metal ions from aqueous solutions - A review. Bioresource Technology, 99(14), 6017-6027. http://dx.doi.org/10.1016/j.biortech.2007.11.064.

Torres-Perez, J., Gerente, C., \& Andres, Y. (2012). Conversion of agricultural residues into activated carbons for water purification: Application to arsenate removal. Journal of Environmental Science and Health Part a-Toxic/Hazardous Substances \& Environmental Engineering, 47(8), 1173-1185. http://dx.doi.org/10/1080/10934529.2012.668390.

Yadav, A. K., Abbassi, R., Gupta, A., \& Dadashzadeh, M. (2013). Removal of fluoride from aqueous solution and groundwater by wheat straw, sawdust and activated bagasse carbon of sugarcane. Ecological Engineering, 52, 211-218. http://dx.doi.org/10.1016/j.ecoleng.2012.12.069.

Zhang, S., Lu, Y., Lin, X., Su, X., \& Zhang, Y. (2014). Removal of fluoride from groundwater by adsorption onto 
La(III)- Al(III) loaded scoria adsorbent. Applied Surface Science, 303, 1-5. http://dx.doi.org/10.1016/j.apsusc.2014.01.169.

\section{Copyrights}

Copyright for this article is retained by the author(s), with first publication rights granted to the journal.

This is an open-access article distributed under the terms and conditions of the Creative Commons Attribution license (http://creativecommons.org/licenses/by/3.0/). 